\section{Performance of Bell Pepper Seeds in Response to Drum Priming with Addition of 24-Epibrassinolide}

\author{
Clíssia Barboza da Silva ${ }^{1}$ and Julio Marcos-Filho \\ Department of Crop Science, University of Sao Paulo, 11 Padua Dias \\ Avenue, Piracicaba, Sao Paulo 13418-900, Brazil \\ Pablo Jourdan \\ Ornamental Plant Germplasm Center, The Ohio State University, Columbus, \\ OH 43210
}

\section{Mark A. Bennett \\ Department of Horticulture and Crop Science, The Ohio State University, Columbus, OH 43210}

Additional index words. growth regulator, seedling growth, seed vigor, antioxidant enzymes, superoxide dismutase, catalase, peroxidase

\begin{abstract}
Drum priming systems are among the most common methods of seed priming for commercial treatment. The supply of water to the seeds is controlled by physical means, and seeds are able to reach a desired moisture content without the use of osmotic solutions for hydration control. The brassinosteroid (BR), 24-epibrassinolide (24-EpiBL), has been shown previously to have a significant effect on seed performance. Therefore, the aim of this study was to verify the feasibility of drum priming associated with added 24-EpiBL on enhancement of bell pepper seed performance. Two bell pepper cultivars (AF-6 and AF-7) were tested, and each cultivar represented, respectively, by three and four seed lots with different initial physiological potentials. Seed performance was determined by evaluating standard germination, initial seedling growth, and changes on the antioxidant activity of superoxide dismutase (SOD), catalase (CAT), and peroxidase (POX). Seed Vigor Imaging System $\left(\right.$ SVIS $\left.^{\circledR}\right)$ was used to assess the initial seedling growth. The nondenaturing polyacrylamide gel electrophoresis (PAGE) technique was used to evaluate possible changes in the enzymatic antioxidant system. Several advantages were verified in the drum priming technique with added 24-EpiBL compared with the traditional procedure (water alone). Germination time was reduced followed by a seedling growth increase. Concomitantly, seed enzymatic activity was improved. However, results showed different response for each enzyme. Drum priming with 24-EpiBL demonstrates viability for commercial treatment and enhancement of bell pepper seeds.
\end{abstract}

Seed vigor is an important attribute of quality for successful food production (Rajjou et al., 2012). Bell pepper (Capsicum annuum L.) multiplication is performed by seeds, which are characterized by slow germination and low uniformity of seedling development (Bosland et al., 2012). As a consequence, direct sowing in the field is not considered as a viable alternative to the more costly plug transplants that are required for uniform field stands. A promising strategy that may permit direct field sowing is the use of primed seeds because such treatment provides for enhancement of the physiological

Received for publication 17 Mar. 2015. Accepted for publication $30 \mathrm{Apr} .2015$.

This work was supported by Sao Paulo Research Foundation, FAPESP (Grant no. 2011/07842-1 and Grant no. 2013/11260-3), and National Council for Scientific and Technological Development, CNPq. We gratefully acknowledge the Ohio State University for supporting the program of visiting researcher scholars in Seed Biology.

${ }^{1}$ To whom reprint requests should be addressed; e-mail clissia_unesp@yahoo.com.br. performance of seeds, which leads to a faster and synchronized development of the seedlings (Bradford et al., 1990; Demir and Okcu, 2004).

Better seed performance after seed priming is, in part, the result of a greater accumulation of germination metabolites (Sliwinska et al., 2009; Varier et al., 2010), and also due to the efficient repair of damage to DNA and membranes, which is enhanced by the controlled water imbibition during the treatment (Ashraf and Bray, 1993; Chen and Arora, 2013). The controlled water imbibition facilitates the early stages of germination, but does not permit completion of the germination process.

Priming with water alone (hydropriming) can improve the efficiency of germination, but imbibition in the presence of other various compounds (nutrients, salicylic acid, growth regulators, etc.) has shown additional benefits which belongs to the group of steroid hormones called BRs, is among the growth regulators included in priming treatment. This bioregulator occurs naturally in plant cells at very low concentrations (Mandava, 1988); therefore, (Parera and Cantliffe, 1994). 24-Epibrassinolide, nano- or micromolar levels may cause remarkable action on seed performance parameters such as germination, seedling growth, and development (Divi and Krishna, 2010; Fridman and Savaldi-Goldstein, 2013; Jiang et al., 2012; Nomura et al., 2007; Tanaka et al., 2003).

The action of 24-EpiBL is also recognized for mediating the induction of genes encoding important antioxidant enzymes under stress conditions, which act on the degradation of toxic substances called reactive oxygen species (ROS). ROS are one of the main causes of seed deterioration and can lead to the loss of seed viability and vigor (Pergo and Ishii-Iwamoto, 2011). ROS production occurs continuously during desiccation, storage, and seed germination (El-Maarouf-Bouteau et al., 2011).

The effect of 24-EpiBL on the activity of antioxidant enzymes might contribute to the tolerance of seeds to stress conditions such as high or low temperatures, salinity, organic pollutants, and pathogen attack (Agami, 2013; Ahammed et al., 2013a, 2013b; Bajguz and Hayat, 2009; Divi and Krishna, 2010; Pradhan et al., 2013; Rady, 2011; Wu et al., 2014; Zhang et al., 2007, 2014). Brassica juncea seedlings treated with 24-EpiBL under salt stress showed similar length to those observed under favorable environmental conditions (Ali et al., 2008). Radish seedlings from seeds primed with 24-EpiBL also showed reduced effects of toxicity by chromium (VI), exhibiting seedling growth similar to those under normal conditions without treatment (Choudhary et al., 2011).

Although there are several studies on priming seeds with 24-EpiBL, these have been limited to laboratory-scale; no study has been reported on the application of 24-EpiBL in a commercial-scale system. Drum priming is one of the most common types of seed priming for commercial treatment in which seeds are hydrated up to a predetermined moisture content by placing them inside a horizontal rotating drum (Bennett and Whipps, 2008; Caseiro et al., 2004; Rowse, 1996; Warren and Bennett, 1997). To investigate whether the combination of added 24-EpiBL with drum priming may be an efficient procedure to enhance germination of bell pepper seeds, a study was carried out on seed lots obtained with different vigor levels (physiological potential). Seed germination, seedling development, and antioxidant enzyme activity from primed seeds with added 24-EpiBL were compared with the outcomes for seeds primed with water alone.

\section{Materials and Methods}

Seed treatment. Two bell pepper cultivars (AF-6 and AF-7), represented, respectively, by three and four hybrid seed lots were obtained with different physiological potentials. Previously, a preliminary experiment was performed to identify a concentration of 24-EpiBL, either $10^{-6}, 10^{-8}$, or $10^{-10} \mathrm{M}$ that would affect germination and vigor of bell pepper during the seed priming (data not shown). The seed performance was affected by $10^{-8} \mathrm{M}$ concentration; thus, a solution with $10^{-8} \mathrm{M} 24$-EpiBL was used for priming seeds $(10 \mathrm{~g})$ in parcels of six cycles of $4 \mathrm{~h}$ (total $24 \mathrm{~h}$ ) with the drum injection 
system. The volume of solution was based on the imbibition curve of each seed lot (Caseiro et al., 2004). Seed moisture content (fresh weight basis) determined by the oven method at $105 \pm$ $3{ }^{\circ} \mathrm{C}$ for $24 \mathrm{~h}$, was $48 \%$ at the conclusion of drum priming. Subsequently, seeds were dried at $25^{\circ} \mathrm{C}$ for $48 \mathrm{~h}$ which reduced the seed moisture content to $7 \%$ (equivalent to the initial seed moisture content). All seed lots were primed with water or with 24-EpiBL solution. Untreated seeds represented the control.

Seed germination. Germination tests were conducted with four replications of 50 seeds. Seeds were distributed on blotter paper moistened with water equivalent to 2.5 times the paper weight, and then placed at bottom of plastic boxes $(28.5 \times 18.5 \times 10.0 \mathrm{~cm})$ under alternating temperature of $20-30{ }^{\circ} \mathrm{C}$. The number of normal seedlings was recorded daily to obtain speed of germination indexes (Maguire, 1962). Germination percentages were calculated at seven (first germination count) and $14 \mathrm{~d}$ (final germination count) after sowing.

Initial seedling growth. Seed Vigor Imaging System software was used to verify the initial seedling growth (Hoffmaster et al., 2005; Kikuti and Marcos-Filho, 2013). Four replications of 25 seeds were used for each seed lot. Seeds were placed in two horizontal rows on the upper third of the surface of previously moistened paper towels. The towels were rolled up and transferred to a germination chamber at $25{ }^{\circ} \mathrm{C}$ and kept for $6 \mathrm{~d}$. Seedlings were then arranged on the surface of a scanner operated by Photosmart software and scanned at 98 dpi resolution. The seedling images were analyzed by the SVIS ${ }^{\circledR}$ software, which calculated data on seed vigor index, seedling length, and seedling uniformity index. The seed vigor index was generated by a combination of growth parameters $(70 \%$ contribution) and seedling uniformity ( $30 \%$ contribution), both based on the maximum possible length of bell pepper seedling $6 \mathrm{~d}$ after sowing. Results are expressed as mean values obtained for each seed lot.

Antioxidant enzyme system. Three grams of frozen seeds were homogenized in a chilled mortar with $9 \mathrm{~mL}$ buffer consisting of $100 \mathrm{~mm}$ potassium phosphate buffer ( $\mathrm{pH} 7.5), 1 \mathrm{~mm}$ ethylenediaminetetraacetic acid, and $3 \mathrm{~mm}$ DL-Dithiothreitol. The homogenate was centrifuged at $12,000 \mathrm{rpm}$ for $10 \mathrm{~min}$ at $4{ }^{\circ} \mathrm{C}$, and the supernatant was subaliquoted and stored at $-80{ }^{\circ} \mathrm{C}$ for further analysis. The concentration of protein in the sample was determined with the method of Bradford (1976) using bovine serum albumin as the standard. Enzyme activity was visualized by staining after running the extracts through nondenaturing 12\% PAGE gels loaded with $40 \mu \mathrm{g}$ protein and electrophoresed at constant current of $20 \mathrm{~mA}$ per gel at $4{ }^{\circ} \mathrm{C}$. The staining protocols used for specific enzymes were as described: SOD (Beauchamp and Fridovich, 1971), CAT (Woodbury et al., 1971), and POX (Hamill and Brewbaker, 1969).

Experimental design and statistical analysis. The data for each cultivar were analyzed separately by analysis of variance in a completely randomized design and factorial scheme of three treatments: control, drum priming with water, and drum priming with 24-EpiBL solution, times the number of seed lots for each cultivar $(n)$. Four replications were used for each seed lot. Means were compared by Tukey's test $(P \leq 0.05)$.

\section{Results}

Overall germination of the seven seed lots was relatively high at $14 \mathrm{~d}$, ranging from $95 \%$ to

Table 1. Germination ${ }^{\mathrm{z}}(\%)$ at $14 \mathrm{~d}$ in bell pepper seed lots of cultivars AF-6 and AF-7. Control seeds (Cont) were untreated, whereas drum-primed seeds with water (Trad) are compared with those primed with 24-epibrassinolide (EpiBL)

\begin{tabular}{|c|c|c|c|c|c|c|c|}
\hline \multirow[b]{2}{*}{ Seed lot } & \multicolumn{3}{|c|}{ Cultivar AF-6 } & \multirow[b]{2}{*}{ Seed lot } & \multicolumn{3}{|c|}{ Cultivar AF-7 } \\
\hline & Cont & Trad & $\overline{\text { EpiBL }}$ & & Cont & Trad & 24-EpiBL \\
\hline$\overline{1}$ & $97 \mathrm{Ab}$ & $98 \mathrm{Aab}$ & $100 \mathrm{Aa}$ & 4 & $98 \mathrm{Aa}$ & $98 \mathrm{Aa}$ & $98 \mathrm{Aa}$ \\
\hline 2 & 99 Aa & $99 \mathrm{Aa}$ & $100 \mathrm{Aa}$ & 5 & $98 \mathrm{Aa}$ & $98 \mathrm{Aa}$ & $99 \mathrm{Aa}$ \\
\hline 3 & $98 \mathrm{Aa}$ & $99 \mathrm{Aa}$ & $100 \mathrm{Aa}$ & 6 & $95 \mathrm{Ab}$ & $98 \mathrm{Aa}$ & $99 \mathrm{Aa}$ \\
\hline- & - & - & - & 7 & $96 \mathrm{Ab}$ & $98 \mathrm{Aa}$ & 99 Аа \\
\hline C.V. $(\%)$ & & 0.7 & & & & 1.8 & \\
\hline
\end{tabular}

${ }^{\mathrm{z}}$ Any two means followed by the same uppercase letters within a column and lowercase letters within a row indicate no statistically significant difference (Tukey's test; $P \leq 0.05$ ).

Table 2. First germination count ${ }^{\mathrm{z}}(\%)$ at $7 \mathrm{~d}$ in bell pepper seed lots of cultivars AF-6 and AF-7. Control seeds (Cont) were untreated whereas drum-primed seeds with water (Trad) are compared with those primed with 24-epibrassinolide (EpiBL).

\begin{tabular}{|c|c|c|c|c|c|c|c|}
\hline \multirow[b]{2}{*}{ Seed lot } & \multicolumn{3}{|c|}{ Cultivar AF-6 } & \multirow[b]{2}{*}{ Seed lot } & \multicolumn{3}{|c|}{ Cultivar AF-7 } \\
\hline & Cont & Trad & $\overline{\text { EpiBL }}$ & & Cont & Trad & 24-EpiBL \\
\hline$\overline{1}$ & $95 \mathrm{Ab}$ & $97 \mathrm{Ab}$ & $99 \mathrm{Aa}$ & 4 & $77 \mathrm{BCb}$ & $95 \mathrm{Aa}$ & $96 \mathrm{Aa}$ \\
\hline 2 & $97 \mathrm{Aa}$ & $99 \mathrm{Aa}$ & $99 \mathrm{Aa}$ & 5 & $87 \mathrm{Aa}$ & $90 \mathrm{Aa}$ & $92 \mathrm{Aa}$ \\
\hline 3 & $98 \mathrm{Ab}$ & $98 \mathrm{Ab}$ & $100 \mathrm{Aa}$ & 6 & $72 \mathrm{Cc}$ & $90 \mathrm{Ab}$ & $96 \mathrm{Aa}$ \\
\hline - & - & - & - & 7 & $86 \mathrm{ABb}$ & $96 \mathrm{Aa}$ & $99 \mathrm{Aa}$ \\
\hline C.V. $(\%)$ & & 1.2 & & & & 6.1 & \\
\hline
\end{tabular}

${ }^{\mathrm{z}}$ Any two means followed by the same uppercase letters within a column and lowercase letters within a row indicate no statistically significant difference (Tukey's test; $P \leq 0.05$ ).

Table 3. Speed of germination index ${ }^{\mathrm{z}}$ (obtained by Maguire method, 1962) in bell pepper seed lots of cultivars AF-6 and AF-7. Control seeds (Cont) were untreated whereas drum-primed seeds with water (Trad) are compared with those primed with 24-epibrassinolide (EpiBL).

\begin{tabular}{|c|c|c|c|c|c|c|c|}
\hline \multirow[b]{2}{*}{ Seed lot } & \multicolumn{3}{|c|}{ Cultivar AF-6 } & \multirow[b]{2}{*}{ Seed lot } & \multicolumn{3}{|c|}{ Cultivar AF-7 } \\
\hline & Cont & Trad & EpiBL & & Cont & Trad & 24-EpiBL \\
\hline$\overline{1}$ & $8.1 \mathrm{Ab}$ & $9.7 \mathrm{Aa}$ & $9.9 \mathrm{Aa}$ & 4 & $6.7 \mathrm{Bc}$ & $7.7 \mathrm{Ab}$ & $8.0 \mathrm{Aa}$ \\
\hline 2 & $8.0 \mathrm{Ab}$ & $9.8 \mathrm{Aa}$ & $9.9 \mathrm{Aa}$ & 5 & $7.1 \mathrm{Ac}$ & $7.7 \mathrm{Ab}$ & $7.9 \mathrm{Aa}$ \\
\hline 3 & $8.1 \mathrm{Ab}$ & $9.9 \mathrm{Aa}$ & $9.9 \mathrm{Aa}$ & 6 & $6.8 \mathrm{Bb}$ & $7.5 \mathrm{Aa}$ & $7.6 \mathrm{Aa}$ \\
\hline - & - & - & - & 7 & $7.2 \mathrm{Ac}$ & $7.6 \mathrm{Ab}$ & $7.9 \mathrm{Aa}$ \\
\hline C.V. $(\%)$ & & 1.5 & & & & 3.0 & \\
\hline
\end{tabular}

${ }^{\mathrm{z}}$ Any two means followed by the same uppercase letters within a column and lowercase letters within a row indicate no statistically significant difference (Tukey's test; $P \leq 0.05$ ).

Table 4. Vigor index ${ }^{z}$ (obtained by Seed Vigor Imaging System software) in bell pepper seed lots of cultivars AF-6 and AF-7. Control seeds (Cont) were untreated whereas drum-primed seeds with water (Trad) are compared with those primed with 24-epibrassinolide (EpiBL).

\begin{tabular}{|c|c|c|c|c|c|c|c|}
\hline \multirow[b]{2}{*}{ Seed lot } & \multicolumn{3}{|c|}{ Cultivar AF-6 } & \multirow[b]{2}{*}{ Seed lot } & \multicolumn{3}{|c|}{ Cultivar AF-7 } \\
\hline & Cont & Trad & EpiBL & & Cont & Trad & 24-EpiBL \\
\hline$\overline{1}$ & $395 \mathrm{Ac}$ & $447 \mathrm{Ab}$ & $510 \mathrm{Aa}$ & 4 & $414 \mathrm{Bb}$ & $430 \mathrm{Ba}$ & $438 \mathrm{Ba}$ \\
\hline 2 & $329 \mathrm{Bc}$ & $419 \mathrm{Bb}$ & $506 \mathrm{Aa}$ & 5 & $464 \mathrm{Ab}$ & $476 \mathrm{Ab}$ & $495 \mathrm{Aa}$ \\
\hline 3 & $375 \mathrm{ABc}$ & $434 \mathrm{ABb}$ & $507 \mathrm{Aa}$ & 6 & $428 \mathrm{Bb}$ & $411 \mathrm{Bb}$ & $483 \mathrm{Aa}$ \\
\hline- & - & - & - & 7 & $421 \mathrm{Ba}$ & $414 \mathrm{Ba}$ & $429 \mathrm{Ba}$ \\
\hline C.V. $(\%)$ & & 7.4 & & & & 6.2 & \\
\hline
\end{tabular}

${ }^{\mathrm{z}}$ Any two means followed by the same uppercase letters within a column and lowercase letters within a row indicate no statistically significant difference (Tukey's test; $P \leq 0.05$ ).

Table 5. Length $(\mathrm{cm})$ of bell pepper seedlings ${ }^{z}$ (obtained by Seed Vigor Imaging System software) of cultivars AF-6 and AF-7. Control seeds (Cont) were untreated whereas drum-primed seeds with water (Trad) are compared with those primed with 24-epibrassinolide (EpiBL).

\begin{tabular}{|c|c|c|c|c|c|c|c|}
\hline \multirow[b]{2}{*}{ Seed lot } & \multicolumn{3}{|c|}{ Cultivar AF-6 } & \multirow[b]{2}{*}{ Seed lot } & \multicolumn{3}{|c|}{ Cultivar AF-7 } \\
\hline & Cont & Trad & $\overline{\text { EpiBL }}$ & & Cont & Trad & 24-EpiBL \\
\hline 1 & $6.6 \mathrm{Ac}$ & $7.6 \mathrm{Ab}$ & $9.6 \mathrm{Aa}$ & 4 & $6.6 \mathrm{ABa}$ & $7.1 \mathrm{Aa}$ & $7.0 \mathrm{ABa}$ \\
\hline 2 & $3.8 \mathrm{Bc}$ & $5.8 \mathrm{Bb}$ & $9.0 \mathrm{Aa}$ & 5 & $7.5 \mathrm{Aa}$ & $7.8 \mathrm{Aa}$ & $8.2 \mathrm{Aa}$ \\
\hline 3 & $6.2 \mathrm{Ac}$ & $8.6 \mathrm{Ab}$ & $10.1 \mathrm{Aa}$ & 6 & $5.9 \mathrm{ABb}$ & $7.5 \mathrm{Aa}$ & $7.8 \mathrm{Aa}$ \\
\hline- & - & - & - & 7 & $5.3 \mathrm{Bb}$ & 5.8 Bab & $6.7 \mathrm{Ba}$ \\
\hline C.V. $(\%)$ & & 10.7 & & & & 9.2 & \\
\hline
\end{tabular}

${ }^{\mathrm{z}}$ Any two means followed by the same uppercase letters within a column and lowercase letters within a row indicate no statistically significant difference (Tukey's test; $P \leq 0.05$ ). 
$100 \%$ regardless of the treatment (Table 1). For cultivar AF-6, there was a small, but statistically significant difference between the germination of drum-primed seeds with 24-EpiBL and water alone for lot 1 . For cultivar AF-7, no differences were noted among the treatments in the absence or presence of 24-EpiBL.

During the first germination count at $7 \mathrm{~d}$ (Table 2), seeds from lots 1,3 , and 6 showed faster germination after drum priming with 24-EpiBL. For example, lot 6 seeds (lowest initial physiological potential in cultivar AF-7) showed mean germination percentages or $72 \%$ for unprimed seed, $90 \%$ for seeds primed with water, but $96 \%$ for seeds primed with 24-EpiBL.

Speed of germination indexes (Maguire, 1962) were also improved after priming (Table 3). Drum priming with 24-EpiBL increased the speed of germination indices of seeds from lots 4, 5, and 7 of cultivar AF-7. However, although increases in the speed of germination indexes of cultivar AF-6 were also verified after priming with 24-EpiBL, these were not significant when compared with traditional drum priming (water alone).

A consistently positive effect of drum priming with 24-EpiBL was reflected in the seed vigor indexes, seedling length, and uniformity of seedling development (Tables 4-6, respectively). The increases were more pronounced for seed lots of cultivar AF- 6 than for those of AF-7, especially for lot 2, seed lot with the lowest initial physiological potential in cultivar AF-6, where seedlings from 24-EpiBL-primed seeds were significantly taller than seedlings from drum priming in absence of this bioregulator (Fig. 1).

Patterns of enzyme activities varied in response to drum priming with 24-EpiBL. Five of the seed lots $(1,2$, and 3-cultivar AF-6; 4 and 7 -cultivar AF-7) showed higher POX activity after drum priming with 24-EpiBL than either the control or drum priming with water alone (Fig. 2). The intensity of SOD band also increased after drum priming with 24-EpiBL (Fig. 3), but except for lot 5, the level of activity did not differ between 24-EpiBL and water alone (Fig. 3). CAT activity also showed increases after traditional drum priming, but treatment with 24-EpiB revealed higher band intensity for most seed lots (Fig. 4).

\section{Discussion}

This study showed that the germination of bell pepper seeds is enhanced by priming with 24-EpiBL and that the drum priming method can be used effectively to achieve the benefits of early germination and uniform seedling development. Drum priming with 24-EpiBL resulted in significantly greater seedling development when compared with drum priming using water alone, especially in seed lots with lower initial physiological potential. Furthermore, 24-EpiBL treatment is associated with increases in antioxidant enzyme activity, which may account for the improved germination performance and seedling development.
Table 6. Uniformity inde $\mathrm{x}^{\mathrm{z}}$ of bell pepper seedling development (obtained bySeed Vigor Imaging System software) of cultivars AF-6 and AF-7. Control seeds (Cont) were untreated whereas drum-primed seeds with water (Trad) are compared with those primed with 24-epibrassinolide (EpiBL).

\begin{tabular}{|c|c|c|c|c|c|c|c|}
\hline \multirow[b]{2}{*}{ Seed lot } & \multicolumn{3}{|c|}{ Cultivar AF-6 } & \multirow[b]{2}{*}{ Seed lot } & \multicolumn{3}{|c|}{ Cultivar AF-7 } \\
\hline & Cont & Trad & $\overline{\text { EpiBL }}$ & & Cont & Trad & 24-EpiBL \\
\hline$\overline{1}$ & $707 \mathrm{Ab}$ & $797 \mathrm{Aab}$ & $820 \mathrm{Aa}$ & 4 & $725 \mathrm{Ab}$ & $789 \mathrm{Aa}$ & $790 \mathrm{Aa}$ \\
\hline 2 & $742 \mathrm{Ab}$ & $862 \mathrm{Aa}$ & $859 \mathrm{Aa}$ & 5 & $790 \mathrm{Ab}$ & $743 \mathrm{Ab}$ & $866 \mathrm{Aa}$ \\
\hline 3 & $686 \mathrm{Bb}$ & $658 \mathrm{Bb}$ & $759 \mathrm{Ba}$ & 6 & $735 \mathrm{Ab}$ & $738 \mathrm{Ab}$ & $820 \mathrm{Aa}$ \\
\hline 一 & 一 & - & 一 & 7 & $788 \mathrm{Ab}$ & $751 \mathrm{Ab}$ & $841 \mathrm{Aa}$ \\
\hline C.V. $(\%)$ & & 8.2 & & & & 6.1 & \\
\hline
\end{tabular}

${ }^{\mathrm{z}}$ Any two means followed by the same uppercase letters within a column and lowercase letters within a row indicate no statistically significant difference (Tukey's test; $P \leq 0.05$ ).

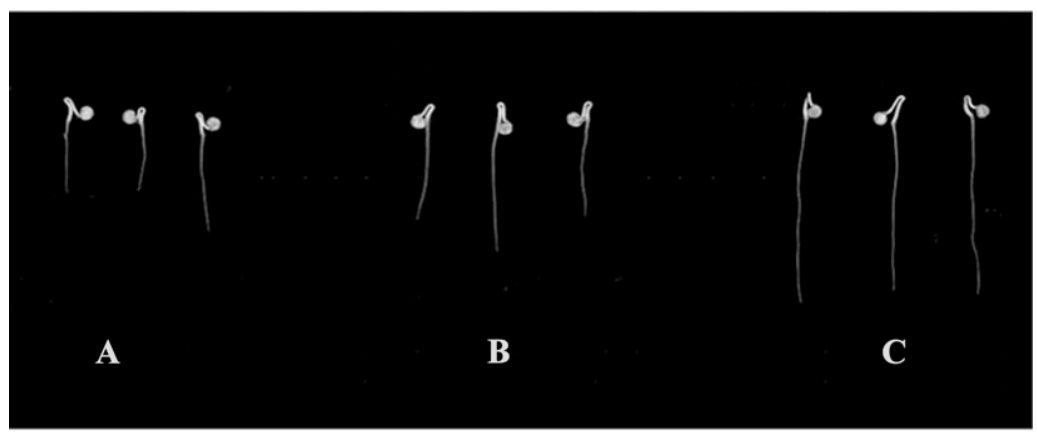

Fig. 1. Six-day-old bell pepper seedlings of cultivar AF-6, lot 2. Seedlings from (A) unprimed seeds; (B) drumprimed seeds using only water (traditional); (C) drum-primed seeds including 24-epibrassinolide.

\section{Cultivar AF-6}
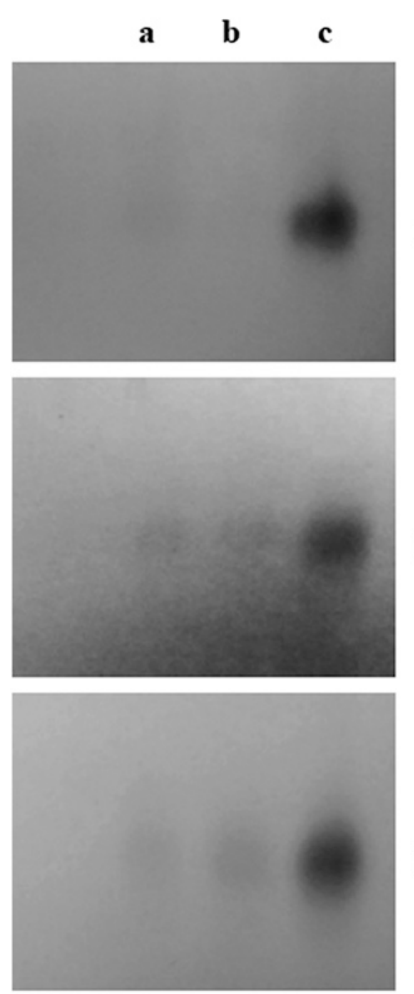

\section{Cultivar AF-7}

a $\quad \mathbf{b} \quad \mathbf{c}$

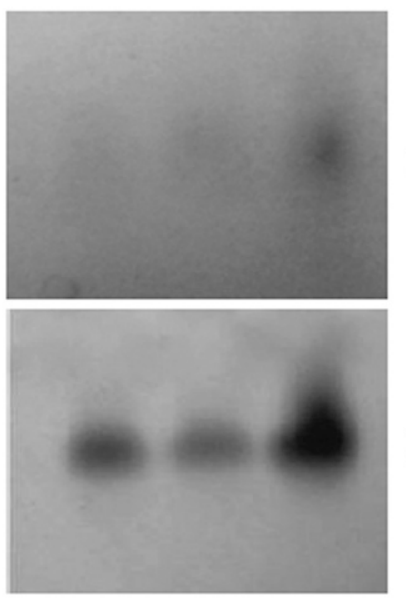

Lot 4

Lot 2

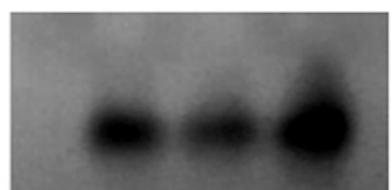

Lot 6

Lot 3

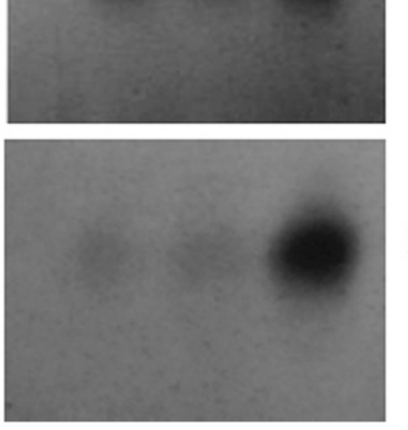

Lot 5

Lot 7
Fig. 2. Activity staining for peroxidase in bell pepper seeds of two cultivars, AF-6 and AF-7, following nondenaturing polyacrylamide gel electrophoresis. Each cultivar was represented by three and four seed lots, respectively. (a) Unprimed seeds; (b) drum-primed seeds using water alone (traditional); (c) drum priming with the addition of 24-epibrassinolide. 
Cultivar AF-6
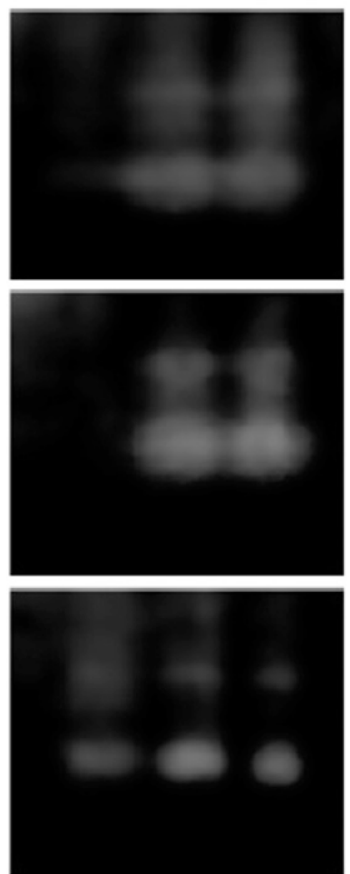

a $\quad$ b c

Cultivar AF-7

a $\quad$ b $\quad$ c

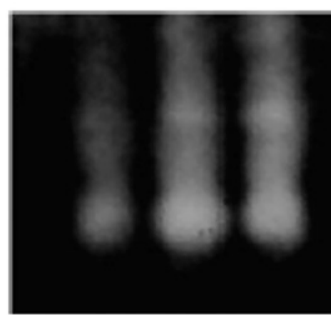

Lot 4

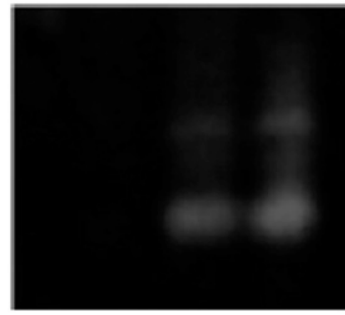

Lot 5

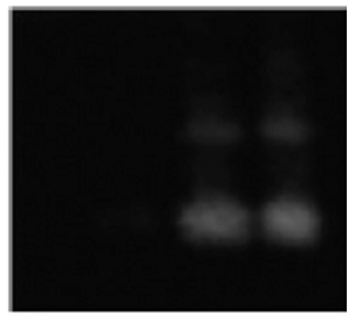

Lot 6

Lot 3

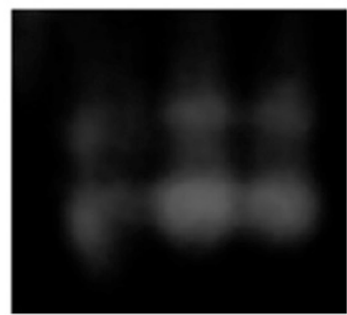

Lot 7

Fig. 3. Activity staining for superoxide dismutase in bell pepper seeds of two cultivars, AF-6 and AF-7, following nondenaturing polyacrylamide gel electrophoresis. Each cultivar was represented by three and four seed lots, respectively. (a) Unprimed seeds; (b) drum-primed seeds using water alone (traditional); (c) drum priming with the addition of 24-epibrassinolide.

For a long time, gibberellins (GA3) and abscisic acid (ABA) had been considered as the two key phytohormones of the seed germination process, with antagonistic roles in the regulation of these events. However, researchers have shown that BRs, in parallel with GA3, can also have an antagonistic effect on ABA, and BRs signaling is essential for successful germination (Divi and Krishna, 2010; Xi and Yu, 2010; Zhang et al., 2009). According to Leubner-Metzger (2001), BRs interact with GA3 to induce the activity of $\beta$-1,3-glucanase class I ( $\beta$ GLU I) and accelerate the rupture of the micropylar endosperm during seed germination. The cell wall, particularly in bell pepper seeds, exerts a high mechanical resistance to growth of the embryonic axis (Watkins and Cantliffe, 1983). Therefore, it seems reasonable to assume that treating bell pepper seeds with BRs may have weakened the cell wall over the embryonic axis and favored germination. Wang et al. (2011) also found an increase in cucumber germination from seeds treated with BRs, and also reported that the beneficial effect of BR can be verified even under salt stress.

In addition to enhanced early germination of bell pepper, this study showed that drum priming with 24-EpiBL causes a significant increase in the subsequent growth of seedlings. Yusuf et al. (2012) also found enhanced growth of mung bean seedlings after seed treatment with 24-EpiBL. Fridman and Savaldi-Goldstein (2013) demonstrated that the growth response of seedlings treated with $24-\mathrm{EpiBL}$ is partly due to the influence of BR in cell expansion. BRs affect the activity of xyloglucan endotransglucosylase/ hydrolase (XTH), an enzyme responsible for cell wall loosening that acts on xyloglucan, the most important hemicellulosic polysaccharide in cell wall. Activity of XTH reduces the resistance between xyloglucan chains and allows for cell expansion (Sun et al., 2005).

Exposure of seeds to BRs may also improve seedlings growth due its important role in cell division. In this context, Fatkhutdinova et al. (2002) found an increase in the mitotic rate of meristematic cells of wheat roots treated with
24-EpiBL, showing similar effects to the roots treated with cytokinins. For Arabidopsis cell suspension culture, the effect of 24-EpiBL was even more remarkable because cell division was verified even in the absence of cytokinins (Hu et al., 2000).

The antioxidant activity of CAT, SOD, and POX in bell pepper seeds after drum priming with 24-EpiBL was also improved. Antioxidant activity during the germination process and the development of embryonic axis is crucial for the decrease of oxides and peroxides, and inhibits possible chemical lesions in the cell. The enzymes CAT, SOD, and POX are part of this antioxidant system. SOD is the first line of defense against superoxide radicals $\left(\mathrm{O}_{2}^{-}\right)$, converting it to oxygen $\left(\mathrm{O}_{2}\right)$ and hydrogen peroxide $\left(\mathrm{H}_{2} \mathrm{O}_{2}\right)$ in mitochondria and the cytosol (Apel and Hirt, 2004). $\mathrm{H}_{2} \mathrm{O}_{2}$ is toxic at high concentrations; CAT converts it to water and oxygen in peroxisomes, and $\mathrm{POXs}$ do so in the cytosol (Ashraf, 2009). $\mathrm{O}_{2}^{-} \mathrm{e}_{2} \mathrm{O}_{2}$ can lead to formation of hydroxyl radical $\left(\mathrm{OH}^{-}\right)$via the Haber-Weiss reaction, which is the most aggressive radical species that can cause extensive cellular damage (Bailly, 2004). Therefore, the balance among SOD, CAT, and POX activities is essential, since, $\mathrm{OH}^{-}$radical is not eliminated enzymatically.

Levels of oxides and peroxides in the cell are directly proportional to seed respiratory rate, because the mitochondrial respiratory chain complex is one of the most important source of ROS (Noctor et al., 2007); electron leak from transport chains generates $\mathrm{O}_{2}^{-}$, and subsequently $\mathrm{H}_{2} \mathrm{O}_{2}$ by $\mathrm{O}_{2}$ dismutation. Germination is closely associated to the increase in the respiration rate and there is a continued increase of ROS during this process, which may cause damage to nucleic acids, lipids, and proteins (Beckman and Ames, 1997; Bray and West, 2005). As a result, the completion of seed germination may be affected by damage on DNA and important seed storage compounds (Kranner and Colville, 2011). The response of SOD, CAT, and POX observed in this study suggests the increase in activity of these ROS scavenging enzymes may provide a potential mechanism that leads seedlings to faster establishment. Seeds with higher detoxification activity at the beginning of imbibition tend to favor the development of the embryonic axis (Bailly, 2004).

Application of 24-EpiBL on bell pepper seeds during drum priming led to enhanced germination and seedlings length in parallel with higher activity of SOD, CAT, and POX. Possibly, one of the reasons for improvement of bell pepper seedling development is induction of antioxidant enzymes activity, which reduces potential damage caused by $\mathrm{O}_{2}^{-}$and $\mathrm{H}_{2} \mathrm{O}_{2}$ during imbibition and reactivation of the seed metabolism, and favors early seedling growth. A study on the dynamics of the antioxidant system and seedling establishment has linked antioxidant enzymatic activity as well as concentration of ROS to the protrusion of the primary root. Chen and Arora (2011) demonstrated that primary root protrusion occurred when the concentration of ROS reached a stationary level, suggesting 

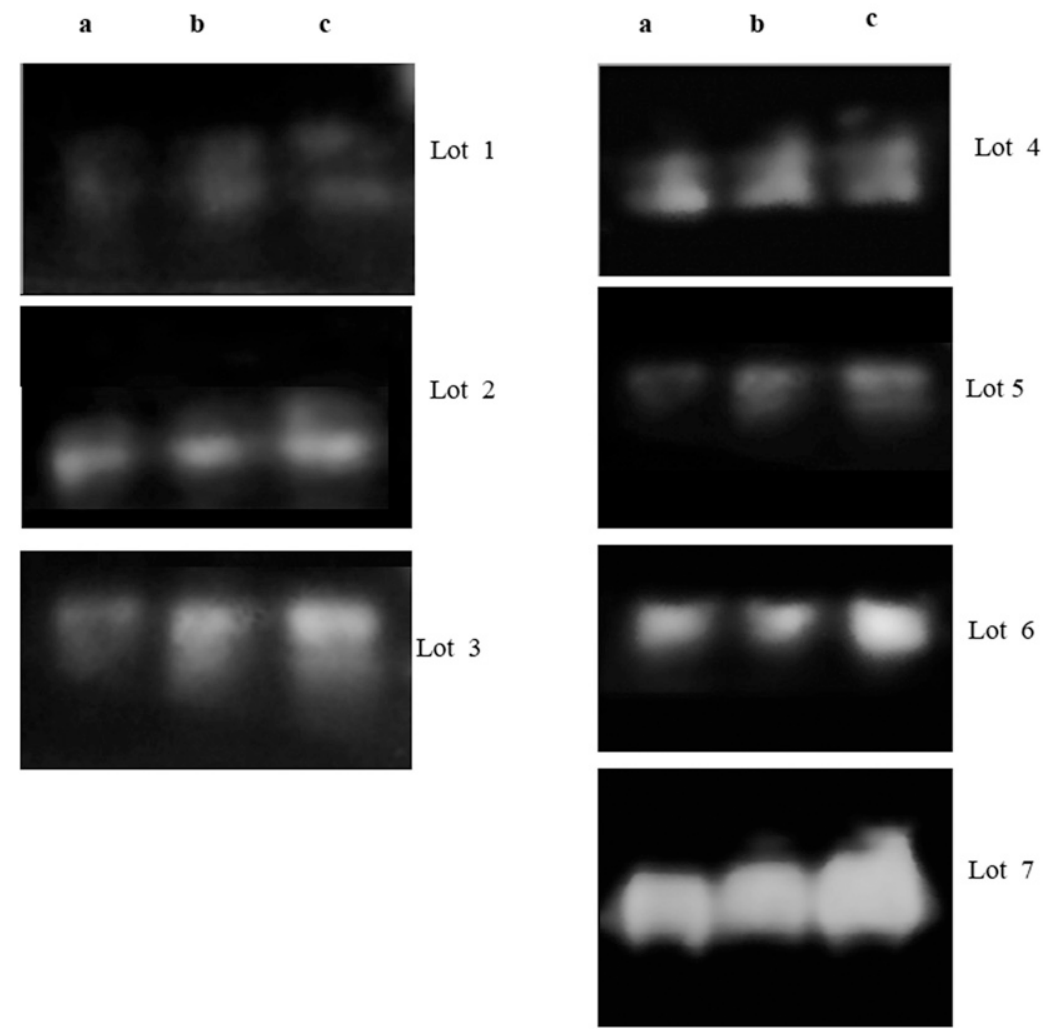

Fig. 4. Activity staining for catalase in bell pepper seeds of two cultivars, AF-6 and AF-7, following nondenaturing polyacrylamide gel electrophoresis. Each cultivar was represented by three and four seed lots, respectively. (a) Unprimed seeds; (b) drum-primed seeds using water alone (traditional); (c) drum priming with the addition of 24-epibrassinolide.

efficient antioxidant enzyme activity is essential for successful germination.

In conclusion, this study showed that drum priming with 24-EpiBL can be used for commercial priming treatment of bell pepper seeds. The advantages achieved by inclusion of 24-EpiBL in the priming treatment can be verified on germination performance, seedling development, and antioxidant enzyme activity. However, it is still necessary to assess whether these beneficial effects on early development will enhance the field performance of seedlings as well as the effect of such priming on seed longevity and persistence during seed storage. Investigation of these important components is currently being performed.

\section{Literature Cited}

Agami, R.A. 2013. Alleviating the adverse effects of $\mathrm{NaCl}$ stress in maize seedlings by pretreating seeds with salicylic acid and 24-epibrassinolide. S. Afr. J. Bot. 88:171-177.

Ahammed, G.J., S.P. Choudhary, S. Chen, X. Xia, K. Shi, Y. Zhou, and J. Yu. 2013a. Role of brassinosteroids in alleviation of phenanthrenecadmium co-contamination-induced photosynthetic inhibition and oxidative stress in tomato. J. Expt. Bot. 64:199-213.

Ahammed, G.J., Y.P. Ruan, J. Zhou, X.J. Xia, K. Shi, Y.H. Zhou, and J.Q. Yu. 2013b. Brassinosteroid alleviates polychlorinated biphenyls-induced oxidative stress by enhancing antioxidant enzymes activity in tomato. Chemosphere 90:2645-2653.

Ali, B., S. Hayat, Q. Fariduddin, and A. Ahmad. 2008. 24-Epibrassinolide protects against the stress generated by salinity and nickel in Brassica juncea. Chemosphere 72:1387-1392.

Apel, K. and H. Hirt. 2004. Reactive oxygen species: Metabolism, oxidative stress, and signal transduction. Annu. Rev. Plant Biol. 55:373-399.

Ashraf, M. 2009. Biotechnological approach of improving plant salt stress using antioxidants as markers. Biotechnol. Adv. 27:84-93.

Ashraf, M. and C.M. Bray. 1993. DNA synthesis in osmoprimed leek (Allium porrum L.) seeds and evidence for repair and replication. Seed Sci. Res. 3:15-23.

Bailly, C. 2004. Active oxygen species and antioxidants in seed biology. Seed Sci. Res. 14:93-107.

Bajguz, A. and S. Hayat. 2009. Effects of brassinosteroids on the plant responses to environmental stresses. Plant Physiol. Biochem. 47:1-8.

Beauchamp, C. and I. Fridovich. 1971. Superoxide dismutase: Improved assays and an assay applicable to acrylamide gels. Anal. Biochem. 44:276-287.

Beckman, K.B. and B.N. Ames. 1997. Oxidants, antioxidants, and aging, p. 201-246. In: J.G. Scandalios (ed.). Oxidative stress and the molecular biology of antioxidant defenses. Cold Spring Harbor Laboratory Press, Cold Spring Harbor, New York.

Bennett, A.J. and J.M. Whipps. 2008. Dual application of beneficial microorganisms to seed during drum priming. Appl. Soil Ecol. 38:83-89.

Bosland, P.W., E.J. Votava, and E.M. Votava. 2012. Peppers: Vegetable and spice capsicums. CABI, Wallingford, England.

Bradford, M.M. 1976. A rapid and sensitive method for the quantitation of microgram quantities of protein utilizing the principle of protein-dye binding. Anal. Biochem. 72:248-254.
Bradford, K.J., J.J. Steiner, and S.E. Trawatha. 1990. Seed priming influence on germination and emergence of pepper seed lots. Crop Sci. 30:718-721.

Bray, C.M. and C.E. West. 2005. DNA repair mechanisms in plants: Crucial sensors and effectors for the maintenance of genome integrity. New Phytol. 168:511-528.

Caseiro, R., M.A. Bennett, and J. Marcos-Filho. 2004. Comparison of three priming techniques for onion seed lots differing in initial seed quality. Seed Sci. Technol. 32:365-375.

Chen, K. and R. Arora. 2011. Dynamics of the antioxidant system during seed osmopriming, post-priming germination, and seedling establishment in spinach (Spinacia oleracea). Plant Sci. 180:212-220.

Chen, K. and R. Arora. 2013. Priming memory invokes seed stress-tolerance. Environ. Exp. Bot. 94:33-45.

Choudhary, S.P., M. Kanwar, R. Bhardwaj, B.D. Gupta, and R.K. Gupta. 2011. Epibrassinolide ameliorates $\mathrm{Cr}$ (VI) stress via influencing the levels of indole-3-acetic acid, abscisic acid, polyamines and antioxidant system of radish seedlings. Chemosphere 84:592-600.

Demir, I. and G. Okcu. 2004. Aerated hydration treatment for improved germination and seedling growth in aubergine (Solanum melongena) and pepper (Capsicum annuum). Ann. Appl. Biol. 144:121-123.

Divi, U.K. and P. Krishna. 2010. Overexpression of the brassinosteroid biosynthetic gene AtDWF4 in Arabidopsis seeds overcomes abscisic acidinduced inhibition of germination and increases cold tolerance in transgenic seedlings. J. Plant Growth Regul. 29:385-393.

El-Maarouf-Bouteau, H., C. Mazuy, F. Corbineau, and C. Bailly. 2011. DNA alteration and programmed cell death during ageing of sunflower seed. J. Expt. Bot. 62:5003-5011.

Fatkhutdinova, R.A., F.M. Shakirova, A.V. Chemeris, B.E. Sabirzhanov, and V.A. Vakhitov. 2002. NOR Activity in wheat species with different ploidy levels treated with phytohormones. Russ. J. Genet. 38:1335-1338.

Fridman, Y. and S. Savaldi-Goldstein. 2013. Brassinosteroids in growth control: How, when and where. Plant Sci. 209:24-31.

Hamill, D.E. and J.L. Brewbaker. 1969. Isoenzyme polymorphism in flowering plants. IV. The peroxidase isoenzymes of maize (Zea mays). Physiol. Plant. 22:945-958.

Hoffmaster, A.F., L. Xu, K. Fujimura, M. Mcdonald, M.A. Bennett, and A.F. Evans. 2005. The Ohio State University Seed Vigor Imaging System (SVIS) for soybean and corn seedlings. Seed Technol. 27:7-24.

Hu, Y., F. Bao, and J. Li. 2000. Promotive effect of brassinosteroids on cell division involves a distinct $C y c D 3$-induction pathway in Arabidopsis. Plant J. 24:693-701.

Jiang, Y.P., F. Cheng, Y.H. Zhou, X.J. Xia, K. Shi, and J.Q. Yu. 2012. Interactive effects of $\mathrm{CO} 2$ enrichment and brassinosteroid on $\mathrm{CO}_{2}$ assimilation and photosynthetic electron transport in Cucumis sativus.. Environ. Expt. Bot. 75:98-106.

Kikuti, A.L.P. and J. Marcos-Filho. 2013. Seedling imaging analysis and traditional tests to assess okra seed vigor. J. Seed Sci. 35:443-448.

Kranner, I. and L.E. Colville. 2011. Metals and seeds: Biochemical and molecular implications and their significance for seed germination. Environ. Expt. Bot. 72:93-105

Leubner-Metzger, G. 2001. Brassinosteroids and gibberellins promote tobacco seed germination by distinct pathways. Planta 213:758763. 
Maguire, J.D. 1962. Speed of germination and in selection and evaluation for seedling emergence and vigor. Crop Sci. 2:176-177.

Mandava, N.B. 1988. Plant growth-promoting brassinosteroids. Annu. Rev. Plant Physiol. Plant Mol. Biol. 39:23-52.

Noctor, G., R. De Paepe, and C.H. Foyer. 2007. Mitochondrial redox biology and homeostasis in plants. Trends Plant Sci. 12:125-134.

Nomura, T., M. Ueno, Y. Yamada, S. Takatsuto, Y. Takeuchi, and T. Yokota. 2007. Roles of brassinosteroids and related mRNAs in pea seed growth and germination. Plant Physiol. 143:1680-1688.

Parera, C.A. and D.J. Cantliffe. 1994. Presowing seed priming. In: J. Janick (ed.). Hort. Rev. 16:109-142.

Pergo, E.M. and E.L. Ishii-Iwamoto. 2011. Changes in energy metabolism and antioxidant defense systems during seed germination of the weed species Ipomoea triloba L. and the responses to allelochemicals. J. Chem. Ecol. 37:500-513.

Pradhan, S.K., R.C. Gupta, and M. Kumar. 2013. Effect of 24-Epibrassinolide on lipid peroxidation and proline in three Brassica species under temperature stress. J. Stress Physiol. Biochem. 9:376-384.

Rady, M.M. 2011. Effect of 24-epibrassinolide on growth, yield, antioxidant system and cadmium content of bean (Phaseolus vulgaris L.) plants under salinity and cadmium stress. Sci. Hort. 129:232-237.

Rajjou, L., M. Duval, K.L. Gallardo, J. Catusse, J. Bally, C. Job, and D. Job. 2012. Seed germination and vigor. Annu. Rev. Plant Biol. 63:507-533.
Rowse, H.R. 1996. Drum Priming-A non-osmotic method of priming seeds. Seed Sci. Technol. 24:281-294.

Sliwinska, E., G.W. Bassel, and J.D. Bewley. 2009. Germination of Arabidopsis thaliana seeds is not completed as a result of elongation of the radicle but of the adjacent transition zone and lower hypocotyls. J. Expt. Bot. 60:3587-3594.

Sun, Y., S. Veerabomma, H.A. Abdel-Mageed, M. Fokar, T. Asami, S. Yoshida, and R.D. Allen. 2005. Brassinosteroid regulates fiber development on cultured cotton ovules. Plant Cell Physiol. 46:1384-1391.

Tanaka, K., Y. Nakamura, T. Asami, S. Yoshida, T. Matsuo, and S. Okamoto. 2003. Physiological roles of brassinosteroids in early growth of Arabidopsis: Brassinosteroids have a synergistic relationship with gibberellin as well as auxin in light-grown hypocotyl elongation. J. Plant Growth Regul. 22:259-271.

Varier, A., A.K. Vari, and M. Dadlani. 2010. The subcellular basis of seed priming. Curr. Sci. 99:450-456.

Wang, B., J. Zhang, X. Xia, and W.H. Zhang. 2011. Ameliorative effect of brassinosteroid and ethylene on germination of cucumber seeds in the presence of sodium chloride. Plant Growth Regulat. 65:407-413.

Warren, J.E. and M.A. Bennett. 1997. Seed hydration using the drum priming system. HortScience 32:1220-1221.

Watkins, J.T. and D.J. Cantliffe. 1983. Mechanical resistance of the seed coat and endosperm during germination of Capsicum annuum at low temperature. Plant Physiol. 72:146-150.
Woodbury, W., A.K. Spencer, and M.A. Stahmann. 1971. An improved procedure using ferricyanide for detecting catalase isozymes. Anal. Biochem. 44:301-305.

Wu, X., X. Yao, J. Chen, Z. Zhu, H. Zhang, and D. Zha. 2014. Brassinosteroids protect photosynthesis and antioxidant system of eggplant seedlings from high-temperature stress. Acta Physiol. Plant. 36:251-261.

Xi, W. and H. Yu. 2010. MOTHER OF FT AND TFL1 regulates seed germination and fertility relevant to the brassinosteroid signaling pathway. Plant Signal. Behav. 5:1315-1317.

Yusuf, M., Q. Fariduddin, and A. Ahmad. 2012. 24-Epibrassinolide modulates growth, nodulation, antioxidant system, and osmolyte in tolerant and sensitive varieties of Vigna radiata under different levels of nickel: A shotgun approach. Plant Physiol. Biochem. 57:143153.

Zhang, S., J. Hu, Y. Zhang, X.J. Xie, and A. Knapp. 2007. Seed priming with brassinolide improves lucerne (Medicago sativa L.) seed germination and seedling growth in relation to physiological changes under salinity stress. Austral. J. Agr. Res. 58:811-815.

Zhang, S., Z. Cai, and X. Wang. 2009. The primary signaling outputs of brassinosteroids are regulated by abscisic acid signaling. Proc. Natl. Acad. Sci. USA 106:4543-4548.

Zhang, Y.P., J. He, S.J. Yang, and Y.Y. Chen. 2014. Exogenous 24-epibrassinolide ameliorates high temperature-induced inhibition of growth and photosynthesis in Cucumismelo. Biol. Plant. 58:311-318. 